\title{
Studies of Acute and Chronic Toxicity of Commercial Herbicides with Glyphosate against Danio rerio
}

\author{
Jofré DM ${ }^{1}$, Alvarez $\mathbf{M}^{1}$, Perez E ${ }^{2}$, Mohamed $\mathrm{F}^{2}$, Jerez $\mathbf{M B}^{3}$, Juri Ayub $\mathbf{M}^{3}$, Enriz RD ${ }^{1}$ and Giannini FA ${ }^{\star}$
}

${ }^{1}$ Área de Química General e Inorgánica. Facultad de Química, Bioquímica y Farmacia, Universidad Nacional de San Luis, San Luis - Argentina. Chacabuco y Pedernera, (5700) San Luis, Argentina

${ }^{2}$ Área de Morfología, Laboratorio de Histología. Facultad de Química, Bioquímica y Farmacia. Universidad Nacional de San Luis- Av. Ejército de los Andes 950, Bloque $/ 1^{\circ}$ piso (5700) San Luis, Argentina

3IMIBIO-SL CONICET, Facultad de Química, Bioquímica y Farmacia, Universidad Nacional de San Luis, Ejercito de los Andes 950, San Luis (5700), Argentina

\begin{abstract}
Glyphosate or $\mathrm{N}$-(phosphonomethyl) glycine is a broad spectrum non-selective systemic herbicide, used to kill weeds, mainly in soybean crops. Nowadays there are many controversies about the intensive use of these herbicides due to the potential environmental impact and the effects on human health. The environmental impacts of commercial Glyphosate formulation Roundup were assessed by evaluation of acute and chronic toxicity of Danio rerio fish.

The effects of glyphosate commercial formulations and glyphosate isopropylamine salt solutions were evaluated in different steps. First the lethal doses of Roundup herbicide toward the experimental models were determined. Subsequently the specie was exposed to sublethal concentrations of both, the commercial preparations and pure glyphosate salt in order to evaluate the chronic toxicity.

Acute toxicity was assessed by calculating the mortality indexes and chronic toxicity by measuring several biochemical parameters such as the activity of marker enzymes like aspartate aminotransferase (AST), alanine aminotransferase (ALT) and acetylcholinesterase (AchE). The registers of histological alterations in liver tissue sections were also considered in this study.

Commercial herbicides produce mortality of $\mathrm{D}$. rerio and sublethal doses of these herbicides and the salt of the pure compound produce effects of chronic toxicity at the liver and muscle level; such are enough causes to limit the potential survival of these organisms in the medium.
\end{abstract}

Keywords: Acute toxicity; Chronic toxicity; Fish; Glyphosate; Danio rerio

\section{Introduction}

Since 1984 the concept of "sustainable development" has been used worldwide to express the linking development with factors such as human resources, food, species, ecosystems, energy and industry. South American countries (Argentina, Brazil) are producers and exporters of raw materials and agricultural inputs in which soybeans is one of the most important. This oilseed currently presents a great interest because it is a product of great economic value.

In order to increase the yield of crops, transgenic varieties resistant to glyphosate or $\mathrm{N}$-(phosphonomethyl) glycine are used. This is a highly water-soluble substance $(10500 \mathrm{mg} / \mathrm{L})$ with a half-life in water of between 3.5 and 90 days [1]. The herbicidal action is due to its ability to inhibit 5-enolpyruvylshikimate-3-phosphatesynthase, an enzyme involved in aromatic amino acids biosynthesis in plants [2].

Glyphosate can be regarded as a compound used extensively in order to control weeds during the soybean crop cycle. This massive and uncontrolled employment has caused concern in urban communities due to the toxicological risks of this pesticide, especially in zones bordering rural areas.

There are multiple commercial formulations of this herbicide, being the most popular and used one known under the trade name Roundup. This herbicide is formulated as the isopropylamine salt of glyphosate with a surfactant called POEA (polyoxyethyleneamine) compound belonging to the family of polyethoxylated alkyl synthesized from fatty acids of animal origin. This last compound is added to the formulation in order to enhance the efficacy of this herbicidal $[3,4]$, however there are a great number of evidences indicating that this compound is the main responsible of the toxic effects of such formulations [5]

A "biomarker" represents a measured response at all levels of biological organization, which may be related to the impact of pollutants [6], it includes responses from organisms in lower organizational levels to the individuals (enzymes, cells, tissues, organs and systems). The term "bio-indicators" refers to responses in the levels of organism, population, community and ecosystem [7].

The fish are used as models to determine the acute toxicity through mortality measure of various species. In addition is evaluated the chronic toxicity by determining possible variations of biochemical parameters such as liver transaminases (AST, ALT) and acetylcholinesterase (AChE) whose altered values may indicate exposure of a few hours or days to several xenobiotics [8]. Histological studies (liver tissue sections or gills) [9] and changes in gene expression are also used.

Our research group has previously used fishes to assess the

*Corresponding author: Giannini FA, Área de Química General e Inorgánica. Facultad de Química, Bioquímica y Farmacia, Universidad Nacional de San Luis, San Luis - Argentina. Chacabuco y Pedernera, (5700) San Luis, Argentina, Tel: 0266-4430515; E-mail: fagian3@gmail.com

Received November 16, 2015; Accepted December 09, 2015; Published December 12, 2015

Citation: Jofré DM, Alvarez M, Perez E, Mohamed F, Jerez MB, et al. (2016) Studies of Acute and Chronic Toxicity of Commercial Herbicides with Glyphosate against Danio rerio. J Environ Anal Toxicol 6: 340. doi:10.4172/2161-0525.1000340

Copyright: @ 2016 Jofré DM, et al. This is an open-access article distributed under the terms of the Creative Commons Attribution License, which permits unrestricted use, distribution, and reproduction in any medium, provided the original author and source are credited. 
potential toxicity of different novel drugs of natural and/or synthetic source [10-12].

To evaluate the acute toxicity we use mortality and chronic toxicity which were assessed by measuring several biochemical parameters such as the activity of marker enzymes like AST, ALT and acetylcholinesterase as well as registering histological alterations in liver tissue sections.

As a second goal, we have used this model for setting tools allowing us to evaluate gene expression at the mRNA level. As proof of principle, we have chosen the monoamine oxidase gene (MAO), which has been shown to be induced by glyphosate in other species [13].

\section{Methods and Materials}

\section{Herbicides and solutions}

To perform the different assays, we used formulations of Roundup ${ }^{\circ}$ with a concentration of the active ingredient of $48 \% \mathrm{w} / \mathrm{v}$. Besides a solution of the pure active ingredient was used: pure glyphosate STD (high purity) $99.7 \%$ provided by Monsanto Argentina. To prepare this solution $3 \mathrm{~g}$ of active substance were dissolved in $500 \mathrm{~mL}$ of distilled water to form a stock solution, which was diluted for various tests.

\section{Biological experimental models}

D. rerio fish were obtained in our laboratory by reproducing adult specimens acquired in commercial shops.

Acute toxicity assay: It was used the technique recommended by the US Fish and Wild life Service [14] which was modified to use a smaller amount of test compounds as was reported by Mascotti et al. Specimens of $D$. rerio were purchased in local businesses and were transferred to our laboratory and placed for 21 days in tanks parked 50 $\mathrm{L}$ of water to adapt to new conditions. During that period they were fed 1 time per day with a (Tetramin ${ }^{\circledast}$ ) specific food and standardized controlled aeration supply; the value of the ambient temperature was a daily average of $23^{\circ} \mathrm{C}$ and water replenishment undertaken to maintain the volume of the ponds. For the experiences we selected specimens to $2.5-3 \mathrm{~cm}$ in length, they showed favorable signs of adaptation considering mobility, fins position and overall external morphology.

Ten adult specimens of D. rerio were exposed for a period of 96 hours to each concentration of test herbicide solutions using five concentrations in each toxicity test (in the range of $100 \mu \mathrm{L} / \mathrm{L}$ to 6.25 $\mu \mathrm{L} / \mathrm{L}$ ). Solutions and specimens were placed in a 10 to $20 \mathrm{~L}$ vessel (ratio of 1 specimen per 1 or $2 \mathrm{~L}$ of water) where they were kept until the end of the evaluations. The numbers of dead specimens in each container were removed every 24 hours. The percentage of mortality was assessed at 96 hs. It was determined the minimum concentration of formulated which produced $100 \%$ mortality $(\mathrm{MC} 100 \% \mathrm{M})$ and the maximum concentration that did not cause mortality $(\mathrm{MC} \% \mathrm{M})$.

Chronic toxicity assays: The specimens were placed in $20 \mathrm{~L}$ containers for a period of 30 days. 10 specimens were placed in each recipient (ratio of 1 specimen per $2 \mathrm{~L}$ of water) and maintained at average ambient temperature of $23^{\circ} \mathrm{C}$ with controlled aeration and fed one time per day with a specific food $\left(\right.$ Tetramin $\left.^{\circ}\right)$ and standardized controlled aeration supply. The specimens were exposed to different sublethal doses considering as such the maximum concentration which did not produced mortality $(\mathrm{MC} 0 \% \mathrm{M})$ determined in the acute toxicity tests. Besides it was used a solution of pure salt of glyphosate at a concentration of $18 \mathrm{mg} / \mathrm{L}$.

Enzymatic assays: Viscera of fish treated and control were separated and macerated. From these macerated the enzymatic activity of AST and ALT were determined. The protocols followed were those specified by the manufacturer (Wiener Lab) based on the use of a specific enzymatic colorimetric method (transaminases 200, Wiener) and already implemented in other toxicity studies conducted by our research group $[15,16]$. For the AchE, muscle tissue flow area was used, the method used is indicated in the protocol specified by the manufacturer (Wiener Lab) based on the use of a kinetic method at 405 $\mathrm{nm}$ (Cholinesterase, Wiener).

\section{Histologic assays}

Liver histological cuts: The animals were sacrificed by rapid decapitation. Then, they were sectioned and the flow area of each fish was dismissed, taking as anatomical reference the anal fin (or the anal orifice). Immediately the trunk was placed in Bouin liquid for fixation during 24 hours. Subsequently the tissue blocks were dehydrated in ethyl alcohol of increasing concentration, clarified in xylene and embedded in paraffin. Sections of 5 microns thick were performed with a sliding microtome Reichert-Jung $\mathrm{Hn} 40$ and were stained with hematoxylin-eosin. The capture of images was performed using an optical microscope Olympus BX-40 with built-in digital camera (Sony SSC-DC50A) and PC connection.

\section{RT-PCR of MAO mRNA}

RNA preparation: Total RNA from viscera was purified using TriReagent, using $70 \mathrm{mg} / \mathrm{mL}$, following the manufacturer instructions. Integrity of RNA was confirmed by agarose electrophoresis and quantification was carried out by absorbance at $260 \mathrm{~nm}$. RNA was treated with RNase-free DNase in order to eliminate potential contamination with genomic DNA.

Primer design and RT-PCR experiments: The following oligonucleotides were designed in order to selectively amplify a 150 bp fragment from the MAO mRNA (GenBank: AY185211.3): Fw_MAO: ACAATGGATAAGATGGGAATGGAG and Rev_ MAO: GTTTACGAACAGAGTGGCAAAG. In order to use as control, the following primers were designed amplifying a 133 bp fragment of the actin mRNA (GenBank: AY222742): Fw_Actin: AACGTCCCAGCCATGTATG and Rev_Actin: GGCAGAGCATAACCCTCATAG. RT-PCR reactions were performed using $0.6 \mu \mathrm{g}$ of total RNA in a final volume of $4 \mu \mathrm{L}$, using the ProtoScript kit (New England Biolabs), following the manufacturer instructions. PCR conditions were as follows; 1 cycle of $94^{\circ} \mathrm{C}$ for $5 \mathrm{~min}$; $35 \mathrm{cycles}$ of $94^{\circ} \mathrm{C}$ for $30 \mathrm{sec}, 60^{\circ} \mathrm{C}$ for $45 \mathrm{sec}, 72^{\circ} \mathrm{C}$ for $30 \mathrm{sec}$; followed by a final elongation step at $72^{\circ} \mathrm{C}$ for $10 \mathrm{~min}$. Amplicons were visualized on $1.5 \%$ agarose electrophoresis.

\section{Statistical analyzes}

The frequency of mortality of acute toxicity tests were compared using Chi Square to analyze and compare the frequencies between mortality rates between different concentrations for the same species studied.

The results of the enzymes activity were analyzed by analysis of variance one-way, after square root transformation of data, in order to homogenize the variances. The subsequent comparisons were performed using t test Tuckey.

In all cases it worked for a significance level of $95 \%$ using statistical soft Graph Pad Instat. 
Citation: Jofré DM, Alvarez M, Perez E, Mohamed F, Jerez MB, et al. (2016) Studies of Acute and Chronic Toxicity of Commercial Herbicides with Glyphosate against Danio rerio. J Environ Anal Toxicol 6: 340. doi:10.4172/2161-0525.1000340

\section{Results and Disscusion}

\section{Acute toxicity}

In the first stage of the work, it was studied the acute toxicity of the commercial herbicide Roundup and an aqueous solution of pure salt of glyphosate (without excipients) against $D$. rerio fish.

The parameter used was mortality evaluating in each case the concentration values of commercial formulation producing $100 \%$ mortality $(\mathrm{MC} 100 \% \mathrm{M})$ and $0 \%$ of mortality $(\mathrm{MC} 0 \% \mathrm{M})$, respectively, These results are shown in Table 1.

Roundup herbicide produces $100 \%$ mortality of the specimens at a concentration of $50 \mu \mathrm{L} / \mathrm{L}$ (equivalent to $24 \mu \mathrm{g} / \mathrm{L}$ of glyphosate salt) and does not produces mortality at $25 \mu \mathrm{L} / \mathrm{L}$ equivalent to $12 \mu \mathrm{g} / \mathrm{L}$ of pure salt). The pure salt solution of glyphosate was evaluated at a concentration of up to $18 \mathrm{mg} / \mathrm{L}$ and it did not produce mortality at such concentration. These results are consistent with multiple studies which have shown that the excipients which are part of the formulation would be responsible for potential toxicity $[5,17]$.

Statistically we observed an effect of all or nothing, with no differences between mortality rates of values higher than $50 \mu \mathrm{L} / \mathrm{L}$ or lower than $25 \mu \mathrm{L} / \mathrm{L}(\mathrm{p} \geq 0.95)$ resulting in the total mortality of fish at values $50 \mu \mathrm{L} / \mathrm{L}(\mathrm{p} \leq 0.000001)$.

\section{Chronic toxicity}

Taking the values $\mathrm{MC} 0 \% \mathrm{M}$ in $\mu \mathrm{L} / \mathrm{L}$ (maximum concentration values that produces $0 \%$ of mortality) as reference $(25 \mu \mathrm{L} / \mathrm{L})$; we carried out different chronic toxicity studies according to the previously described methodology.

Enzymatic assays: The liver is an organ used by fish to perform various functions related to the metabolism of xenobiotics [18]. There is a group of liver enzymes that indicate this activity among which stand out Glutathione-S-transferases (GST); ALT and AST which catalyzes the conjugation of glutathione (GSH) with a variety of electrophilic metabolites involved in the detoxification process [19]. These transaminases (AST and ALT) are enzymes widely distributed in the body and their normal activity in serum is very low or zero. It has been shown that the activity of these enzymes vary in fish exposed to various contaminants as herbicides [15], besides an organic low level contamination can lead to increased GST hepatic activity in fish [20] or a significant reduction [21].

Acetylcholinesterase (AChE) belongs to a family of enzymes defined as a group of serine esterases capable of hydrolyzing choline esters such as acetylcholine. Cholinesterase has a very wide distribution, from unicellular organisms, plants, invertebrates and vertebrates in which appears in very early stages of embryonic development before the synaptogenesis, and is predominant in muscle and nervous system.

The inhibition of AChE in brain tissue or other organs: such as muscle is considered as the most specific and sensible biomarker for insecticides possessing carbamate and organophosphate in freshwater and marine water fish [22-24].

When AChE is inhibited, acetylcholine hydrolysis it is not allowed, resulting in continuous transmission of impulses that causes an over stimulation of nerve cells. This may result in muscle contraction and a respiratory failure [25].

Enzymatic activity studies were performed on fish for Roundup and the solution of pure salt of glyphosate for $D$. rerio. Thus, we determined the liver enzyme levels (AST and ALT) and acetylcholinesterase (AChE) of the different specimens and the results obtained are shown in Table 2.

According to the data of Table 2 it can be seen that for the liver transaminases the values obtained for the specimens are significantly increased with respect to the values of the control group. The mean of the average value of the control group for AST was $56 \mathrm{U} / \mathrm{L}$ and 57.33 $\mathrm{U} / \mathrm{L}$ for ALT; while the average value of the group exposed to herbicide was $122 \mathrm{U} / \mathrm{L}$ for AST and $130 \mathrm{U} / \mathrm{L}$ for ALT.

Regarding the activity of AchE in fish muscle, we observed a decrease in enzyme activity according to values of the control group. This enzyme is considered as one of the most significant environmental pollution biomarkers in fish, therefore the results demonstrate effects of chronic toxicity of the solutions tested at sublethal doses.

It is interesting to note that the values of transaminases and AchE for the set exposed to the solution of pure salt of glyphosate did not show mortality in acute toxicity assay; however it produces significant increase in the enzymes evaluated. Due to the levels of these enzymes might be considered as biomarkers of toxicity, it is clear that exposure for a period of 30 days at doses $\mathrm{MC} \% \mathrm{M}$ of the commercial herbicide and the solution of pure salt of glyphosate at $18 \mathrm{mg} / \mathrm{L}$ might produce chronic toxicity effects on $D$. rerio fish.

The analysis of variance for both transaminases and AchE shows very significant differences $(p \leq 0.0001)$. Comparisons between pairs of measurements (samples and control) were performed using TukeyKramer test.

\section{Histological tests}

Hepatic histological sections: Histological sections were performed looking for cellular morphological changes indicating toxicity. It was observed that the liver parenchyma of $D$. rerio of the control group (Figure 1A) exhibits a characteristic histoarchitecture. Hepatocytes show round or oval nucleus with smooth or slightly granular chromatin and eosinophilic cytoplasm. Sinusoids displayed typical and bile ducts subtly detectable by the presence of erythrocytes.

The sample which was exposed to the pure salt of glyphosate (Figure 1B) shows a hepatic parenchyma with moderate signs of alterations of its histoarchitecture. Vacuolated cells with irregular nucleus and cytoplasm were observed at different stages of degeneration. The dilated sinusoids are a suggestive evidence of hyperemia.

Finally the liver tissue exposed to Roundup MC0\%M (Figure 1C)

\begin{tabular}{|c|c|c|c|c|}
\hline \multirow{2}{*}{ Species } & \multicolumn{2}{|c|}{ Roundup $\boldsymbol{\mu L} / \mathbf{L}$} & \multicolumn{2}{c|}{ Solution of pure salt $\mathbf{~ m g / L}$} \\
\cline { 2 - 5 } & A & B & A & B \\
\hline Danio rerio & 50 & 25 & - & $\geq 18$ \\
\hline
\end{tabular}

A: $\mathbf{M C 1 0 0 \% M}$ in $\mu \mathrm{L} / \mathrm{L}$ (minimum concentration values that produces $100 \%$ mortality)

B: $\mathbf{M C 0} \% \mathrm{M}$ in $\mu \mathrm{L} / \mathrm{L}$ (maximum concentration values that produces $0 \%$ of mortality) Table 1: Acute toxicity values of the commercial herbicide Roundup and an aqueous solution of pure salt of glyphosate.

\begin{tabular}{|c|c|c|c|}
\hline Sample & $\begin{array}{c}\text { AST (U/L) } \\
\mathrm{X} \pm \mathrm{SD}\end{array}$ & $\begin{array}{c}\text { ALT (U/L) } \\
\mathrm{X} \pm \mathrm{SD}\end{array}$ & $\begin{array}{c}\text { AChE (U/L) } \\
\mathrm{X} \pm \mathrm{SD}\end{array}$ \\
\hline Control & $56 \pm 4.89$ & $57.33 \pm 2.49$ & $22.36 \pm 1.51$ \\
\hline Roundup $25 \mu \mathrm{L} / \mathrm{L}$ & $122 \pm 6.16$ & $130 \pm 8.52$ & $6.35 \pm 0.55$ \\
\hline $\begin{array}{c}\text { solution of pure salt } \\
18 \mathrm{mg} / \mathrm{L}\end{array}$ & $100 \pm 1.63$ & $106 \pm 2.94$ & $10.85 \pm 0.25$ \\
\hline
\end{tabular}

Table 2: Enzymatic activity values for Roundup and the solution of pure salt of glyphosate for $D$. rerio. 

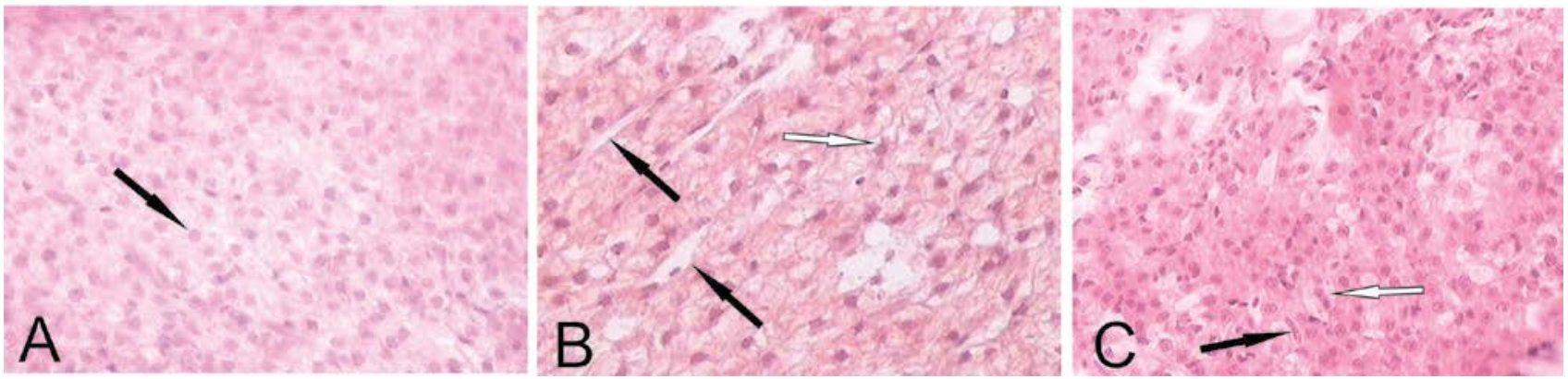

Figure 1: Photography of hepatic histological section of $D$. rerio. A: liver parenchyma of $D$. rerio in control group. B: sample exposed to pure glyphosate salt solution and C: liver tissue exposed to Roundup MCO\%M.

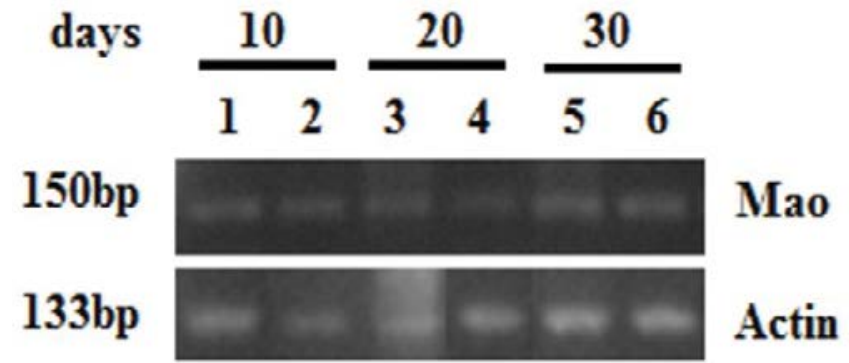

Figure 2: RT-PCR assay for determining relative mRNA expression level of MAO gene. Expression was determined in samples from control (lanes 1, 3 and 5 ) and treated fish (lanes 2, 4 and 6) with Roundup for 10, 20 or 30 days. The housekeeping gene $\beta$-actin was amplified as constitutive control.

showed a marked loss of parenchymal histoarchitecture; showing irregular nucleus with clumped chromatin, hypertrophic and vacuolated nucleus. A great quantity of cytoplasm exhibited many cytoplasmic vacuoles and a marked degeneration. Damaged and dilated blood vessels were frequently observed, probably due to increased blood flow known as hyperemia.

It must be considered that sublethal doses of these herbicides and the salt of the pure compound produce effects of chronic toxicity at the liver and muscle; such are enough causes to limit the potential survival of these organisms in the medium. Although it is only possible to assess these effects for the specie studied here; these results adding with the extensive literature reporting similar effects on other species are worrying considering the wide use with these herbicides in countries of South America.

\section{MAO mRNA expression analysis}

Monoamine Oxidases (MAO) are enzymes located in the outer mitochondrial membrane. This enzyme is part of a diverse family of enzymes involved in metabolizing various monoamines, diamines and polyamines produced endogenously or absorbed in the diet, as well as toxic xenobiotics [26,27]. It has been reported that xenobiotics induce the expression of the genes encoding for these enzymes. Mammals, including humans, possess two forms of this enzyme, which are transcribed from separate genes, named as MAO A and MAO B. In contrast, it has been reported that zebrafish, a popular teleost organism suitable for various pharmacological applications, harbors a single MAO gene.

In order to determine the effect of glyphosate-based formulations on expression of MAO, groups of two fish were exposed to Roundup or water, as a control. Total RNA was extracted from the whole visceral homogenates of control and treated fish after 10,20 and 30 days of exposure. RNA was submitted to reverse transcription and the cDNAs corresponding to each sample was used as template to amplify MAO and Actin sequences. In contrast to other analysis, we have found basal expression of MAO, and no induction by glyphosate could be detected (Figure 2). The described protocol would be used as basis for analyzing the expression of other potential target genes employing both end point as well as real time PCR in future studies using this experimental model.

\section{Acknowledgements}

This work was supported by grants from UNSL PROICO 22/Q027 and ANPC y TPICT 1832. R D E and MYA are members of the research career of CONICET. The authors thank Angelina Bernardi for technical assistance. "All procedures performed in studies involving animals were in accordance with the ethical standards of CICUA (Comité Institucional de Cuidado y Uso de Animales) of Universidad Nacional de San Luis at which the studies were conducted."

\section{References}

1. Tomlin CDS (2006) The Pesticide Manual: A World Compendium. 14th edn British Crop Protection Council: Hampshire, UK. pp: 545-548.

2. Mallory-Smith CA, Ratzinger EJ Jr (2003) Revised classification of herbicides by sites of action for weed resistance management Strategies. Weed Technol 17: 605-619.

3. Relyea RA (2005) The lethal impacts of Roundup and predatory stress on six species of North American tadpoles. Arch Environ Contam Toxicol 48: 351-357.

4. Tsui MTK, Chu LM (2004) Comparative toxicity of glyphosate-based herbicides: Aqueous and sediment porewater exposures. Arch Environ Contam Toxicol 46 316-323.

5. Folmar LC, Sanders HO, Julin AM (1979) Toxicity of the herbicide glyphosphate and several of its formulations to fish and aquatic invertebrates. Arch Environ Contam Toxicol 8: 269-278.

6. Melacon $M$ (1995) Bioindicators used in aquatic and terrestrial monitoring In David JH, Barnett A R, Allen Burton G Jr, Cairns J Jr (Eds) Handbook of Ecotoxicology. Boca Raton, EEUU: Lewis. 220-240.

7. Depledge M, Aagaard A, Gyorkos P (1995) Assessment of trace metal toxicity using molecular, physiological and behavioral biomarkers. Mar Pollut Bull 21: $19-27$.

8. Ludke JL, Hill EF, Dieter MP (1975) Cholinesterase (ChE) response and related mortality among birds fed ChE inhibitors. Arch Environ Contam Toxicol 3: 1-21.

9. Jiraungkoorskul W, Upatham ES, Kruatrachue M, Sahaphong S, VichasriGrams S, et al. (2003) Biochemical and histopathological effects of glyphosate herbicide on Nile tilapia (Oreochromis niloticus). Environ Toxicol 18: 260-267.

10. Bisogno F, Mascoti L, Sanchez C, Garibotto F, Giannini F, et al. (2007) Structure-antifungal activity relationship of cinnamic acid derivatives. J Agric Food Chem 55: 10635-10640.

11. Garibotto FM, Garro AD, Masman MF, Rodríguez AM, Luiten PG, et al. (2010) New small-size peptides possessing antifungal activity. Bioorg Med Chem 18: 158-167. 
Citation: Jofré DM, Alvarez M, Perez E, Mohamed F, Jerez MB, et al. (2016) Studies of Acute and Chronic Toxicity of Commercial Herbicides with Glyphosate against Danio rerio. J Environ Anal Toxicol 6: 340. doi:10.4172/2161-0525.1000340

12. Mascotti ML, Enriz RD, Giannini FA (2008) Acute toxicity study of commercial antifungal drugs using Poecilia reticulata. Lat Am J Pharm 27: 904-905.

13. Boutet I, Tanguyb A, Moraga D (2004) Molecular identification and expression of two non-P450 enzymes, monoamine oxidase $A$ and flavin-containing monooxygenase 2 , involved in phase I of xenobiotic biotransformation in the Pacific oyster, Crassostrea gigas. Biochim Biophys Acta 1679: 29-36.

14. Johnson WW, Finley MT (1980) Handbook of Acute Toxicity of Chemicals to Fish and Aquatic Invertebrates. Washington DC: United States Department of the Interior Fish and Wildlife Service. Resource Publication 137.

15. Alvarez M, Gimenez IT, Saitua H, Enriz RD, Giannini FA (2012) Toxicidad en peces de herbicidas formulados con glifosato. Acta Toxicol Argent 20: 5-13.

16. Jofré DM, Germanó García MJ, Salcedo R, Alvarez M, Enriz RD, et al. (2013) Fish Toxicity of commercial herbicides formulated with glyphosate. Journal of Environmental Toxicology. 3: 199

17. Domínguez CG, Mejía SJ, Santos MGE, Martínez RR (2008) Analysis of the toxicity of glyphosate and Faena ${ }^{\circledR}$ using the freshwater invertebrates Daphnia magna and Lecane quadridentata. Environ Toxicol Chem 90: 377-384.

18. Jimenez JJ, Stegeman D (1990) Detoxification enzymes as indicators of environmental stress on fish ,in: S.M. Adams (Ed) Biological Indicators of Stress in Fish, American Fisheries Symposium, AFS, Bathesda. 8: 67-79.

19. van der Oost R, Beyer J, Vermeulen NP (2003) Fish bioaccumulation and biomarkers in environmental risk assessment: a review. Environ Toxicol Pharmacol 13: 57-149.
20. Machala M, Petrivalský M, Nezveda K, Ulrico R, Dušek L, et al. (1997) Responses of carp hepatopancreatic 7-ethoxyresorufin-O-deethylase and glutathione-dependent enzymes to organic pollutants - a field study. Environ Toxicol Chem 16: 1410-1416.

21. Langiano VC, Martinez CBR (2008) Toxicity and Effects of a GlyphosateBased Herbicide on the Neotropical Fish Prochilodus Lineatus. Comp Biochem Physiol C Toxicol Pharmacol 147: 222-231.

22. Bastos VLFC, Bastos C, Lima JS, Faria MCV (1991) Brain acetylcolinesterases as an in vitro detector of organophosphorus insecticides in water. Wat Res 25: $835-840$.

23. Grue CE, Gilbert PL, Seely ME (1997) Neurophysiological and behaviora changes in non-target wildlife exposed to organophosphate and carbamate pesticides: thermoregulation, food consumption and reproduction. Am Zool 37: 369-388.

24. Sturm A, de Silva DA, Assis HC, Hansen PD (1999) Entomological characterization and potential use in the monitoring of neurotoxic contamination Mar Environ Res 47: 389-398.

25. Ecobichon DJ (1991) Organophosphate-Sensitive Cholinergic Receptors In: Amdur MO, Doull J, Klassen CD (editors). Casaren and Doull Pergammon Press, New York, USA. pp: 565-622.

26. Gong B, Boor PJ (2006) The role of amine oxidases in xenobiotic metabolism. Expert Opin Drug Metab Toxicol 2: 559-571.

27. Aldeco M, Arslan BK, Edmondson DE (2011) Catalytic and inhibitor binding properties of zebrafish monoamine oxidase (ZMAO): comparisons with human MAO A and MAO B. Comp Biochem Physiol B Biochem Mol Biol 159: 78-83. 